\title{
ХІРУРГІЯ
}

\section{ВИБІР МЕТОДУ РЕКОНСТРУКЦІЇ ДЕФЕКТІВ ПОКРИВНИХ ТКАНИН ТУЛУБА ТА КІНЦІВОК У ТРАВМОВАНИХ ХВОРИХ}

\begin{abstract}
Резюме. Об'єм реконструктивних втручань із відновлення десректів покривних тканин, які виникають унаслідок травматичного ушкодження, визначає результат як з функціональної, так і з естетичної точки зору.

Мета дослідження - обрати оптимальний метод відновно-реконструктивного втручання із закриття ранових десректів тулуба та кінцівок після травми.

Матеріали і методи. У роботі проаналізовано дані 242 хворих із десектами покривних тканин тулуба та кінцівок, які виникли унаслідок механічного ушкодження за період 2008-2016 рр. Пацієнтам виконали 697 оперативних втручань, 3 них 492 (70,6 \%) операцій з приводу відновлення ушкоджених тканин.

Результати досліджень та їх обговорення. Хворих поділили на 4 групи залежно від розмірів, глибини та ступеня ушкодження м'яких тканин та інших структур тулуба й кінцівок. Перша група - $44(18,2$ \%) хворих з обмеженою (до 5 см у діаметрі) ділянкою ушкодження шкіри та підлеглих тканин до глибокої фрасції. Їм було виконано 61 (8,8 \%) втручання. Друга група - 67 $(27,7$ \%) хворих із великою та надвеликою рановою поверхнею й ушкодженням м'яких тканин нижче глибокої фрасції. У цій групі виконано 144 (20,6 \%) оперативних втручань. Третю групу склали 90 (37,2 \%) пацієнтів з десектами покривних тканин, які виникли разом або унаслідок ушкодження кістково-суглобового апарату. Було виконано 272 (39 \%) операцій. Четверта група - 41 (16,9 \%) хворих з поєднаною або множинною травмою, що супроводжується ушкодженням магістральних судин, нервів частковим або повним відокремленням кінцівки. В цій групі було виконано 220 (31,6 \%) операцій.

Висновки. Використання васкуляризованих клаптів у 21,3 \% усіх можливих реконструкцій підвищило функціональні та косметичні результати лікування, знизило кількість ішемічних розладів та запальних процесів (1,9\% післяопераційних ускладнень). Ретельний підхід до вибору відновного втручання дефектів покривних тканин, які зумовлені механічними ушкодженнями, дозволив досягти задовільних результатів у 98,9 \% випадків.
\end{abstract}

Ключові слова: рановий дефект; ділянка ушкодження; кінцівки; клапоть; реконструктивні втручання.

ВСТУП Об'єм реконструктивних втручань із відновлення дефектів покривних тканин, які виникають унаслідок травматичного ушкодження, визначає результат як з функціональної, так і з естетичної точки зору [4, 7].

За останнє десятиріччя арсенал пластичного хірурга щодо відновлення покривних тканин значно зріс, а саме: від використання розщеплених вільних аутодермотрансплантатів та складних мігруючих комплексів тканин до перорорантних клаптів $[2,3,6]$. Тому вибір оптимального виду оперативного втручання достатньо складний, враховуючи переваги та недоліки кожного з них [1, 5].

Метою дослідження було обрати оптимальний метод відновно-реконструктивного втручання із закриття ранових десектів тулуба та кінцівок після травми.

МАТЕРІАЛИ І МЕТОДИ В роботі проаналізовано дані 242 хворих із дефектами покривних тканин тулуба та кінцівок, які виникли унаслідок механічного ушкодження за період 2008-2016 рр. Пацієнтам було виконано 697 оперативних втручань, з них 492 (70,6 \%) операцій з приводу відновлення ушкоджених тканин.

Усіх хворих поділили на 4 групи залежно від розмірів, глибини та ступеня ушкодження м'яких тканин та інших структур тулуба й кінцівок. Перша група - 44 (18,2 \%) хворих з обмеженою (до 5 см у діаметрі) ділянкою ушкодження шкіри та підлеглих тканин до глибокої фрасції. Їм виконали 61 (8,8 \%) втручання.

Друга група - 67 (27,7 \%) пацієнтів із великою та надвеликою рановою поверхнею й ушкодженням м'яких тканин нижче глибокої фрасції. У цій групі виконано 144 $(20,6 \%)$ оперативних втручань.

Третю групу склали 90 (37,2 \%) хворих із дефектами покривних тканин, які виникли разом або унаслідок ушко- дження кістково-суглобового апарату. Було виконано 272 (39 \%) операцій.

Четверта група - 41 (16,9 \%) пацієнт із поєднаною або множинною травмою, що супроводжується ушкодженням магістральних судин, нервів частковим або повним відокремленням кінцівки. В цій групі було виконано 220 (31,6 \%) операції.

Умовно поділили судини на два основні типи, осьовий та сегментарний, що визначає принципово різні можливості виділення та пересадки комплексів тканин.

За складом тканин клапті поділяють на дві групи. До простих клаптів відносять комплекси тканин, які утворені однорідною тканиною, складні - двома й більше видами тканин. У даному дослідженні з усієї групи простих клаптів використали лише шкірні, як найлегші та ефективніші у використанні. Десректи покривних тканин (ДПТ) зумовлені механічними фракторами, відрізняються великими анатомічними та фрункціональними змінами, що супроводжуються кровотечею, крововиливами в тканини, розривами та розтрощеннями органів, частковим або повним відокремленням сегментів чи частин тіла. Ця травма супроводжується ішемією тканин, контамінацією бактерій й тому потребує максимально швидкого та ефективного способу закриття РП, яким є використання простого вільного розщепленого трансплантата (табл. 1).

Вільну шкірну пластику розщепленим трансплантатом використовували у хворих усіх груп (першої - четвертої) з поверхневими гранулюючими РП різних розмірів (табл. 2). Товщина трансплантатів коливалася від 0,25 мм до 0,6 мм.

При розмірі РП 1 \% (розміри долоні хворого) і менше застосовували методику аутодеромпластики за Тіршем, 
Таблиця 1. Кількість вільних шкірних пластик у хворих із дефектами покривних тканин залежно від ділянки ушкодження

\begin{tabular}{|l|c|c|c|c|}
\hline \multicolumn{1}{|c|}{ Ділянка ушкодження } & $\begin{array}{c}\text { Перша група } \\
(\mathrm{n}=44) \\
(\%)\end{array}$ & $\begin{array}{c}\text { Друга група } \\
(\mathrm{n}=67) \\
(\%)\end{array}$ & $\begin{array}{c}\text { Третя група } \\
(\mathrm{n}=90) \\
(\%)\end{array}$ & $\begin{array}{c}\text { Четверта група } \\
(\mathrm{n}=41) \\
(\%)\end{array}$ \\
\hline Верхня кінцівка & $13(30,23)$ & $7(12,3)$ & $10(10,2)$ & $11(27,5)$ \\
\hline Нижня кінцівка & $30(69,77)$ & $49(86)$ & $87(88,8)$ & $19(47,5)$ \\
\hline Тулуб & - & $1(1,7)$ & $1(1)$ & $10(25)$ \\
\hline Усього & $43(100)$ & $57(100)$ & $98(100)$ & $40(100)$ \\
\hline
\end{tabular}

коли один або декілька трансплантатів отримували за допомогою одноразового леза бритви (товщина шару $0,25-0,3$ мм).

При правильному заборі шкірного трансплантата (товщина не перевищувала двох третин дерми) загоєння донорської зони проходило без фрункціонального та естетичного десріциту. В усіх групах (перша - четверта) хворих ускладнень при загоєнні в донорській ділянці не було.

На етапі підготовки до операції проводили очищення рани від некротичних тканин, усунення крайових порожнин, додаткове дренування гематом. Етапні некректомії виконували хірургічним способом чи з використанням пов'язок, кремів, мазей для видалення ранового вмісту й боротьби з мікрофрлорою.

Трансплантацію проводили за стандартною методикою. Аутодермотрансплантат розкладали на РП. При двох й більше кількості трансплантатів, їх краї ретельно зіставляли, за необхідності фріксували одиничними швами на краях.

У 3 (3/238; 1,3 \%) випадках (2 в другій та 1 у третій групах) виник частковий лізис аутодермотрансплантатів, що потребувало додаткових оперативних втручань. Ускладнень після повторних операцій не було. Аутодермопластику також використовували в комбінації з іншими видами пластики (табл. 2).

За допомогою пересадки вільних розщеплених шкірних трансплантатів максимально швидко й в короткі терміни закривали поверхневі гранулюючі РП, різні за площею. Особливо важливо це було у пацієнтів із множинними та поєднаними ушкодженнями, які потребували багатоетапних втручань на різних анатомічних структу- рах. Основним недоліком цієї методики було фрормування неповноцінного, структурного та естетичного, шкірного покриву в ділянці ушкодження.

Найоптимальнішу ціль дослідження досягали при використанні різних видів клаптів на живильній ніжці (табл. 3).

У першій групі (44 (44/242; 18,2 \%) хворих з обмеженою (до 5 см у діаметрі) ділянкою ушкодження шкіри та підлеглих тканин до глибокої фрасції) складні клапті для закриття РП не використовували.

Показаннями для пластики складними клаптями були:

- ділянка ушкодження - фрункціонально напруженою частиною тіла (проекція суглобів) чи підлягала великій механічній напрузі (п'ята, підошва);

- погане кровопостачання ділянки дефректу та покривних тканин навколо;

- глибина дефекту, в дні рани вільно розташовувалися кістка, суглоб, сухожилки, судина, нерв;

- усунення контурних десректів тулуба та кінцівок.

Вибір донорської ділянки залежав від віку хворого, супутньої патології, особливостей регіональної гемодинаміки в ділянці ушкодження. Основним при обранні клаптя принципом була відстань до зони ушкодження чим ближче до десректу, тим кращий результат оперативного втручання. Важливою умовою було те, щоб використані клапті в донорській ділянці не спричиняли фрункціональних порушень й мали мінімальний естетичний десріцит.

Клапоть на живильній ніжці може бути викроєний 3 покривних тканин, які безпосередньо прилягають до десекту, із тканин, що розташовані близько до дефекту чи віддалених анатомічних зон.

Таблиця 2. Кількість пластик вільним розщепленим шкірним трансплантатом у пацієнтів із десектами покривних тканин

\begin{tabular}{|l|c|c|}
\hline \multicolumn{1}{|c|}{ Група хворих } & $\begin{array}{c}\text { Кількість пластик вільним розщепленим шкірним } \\
\text { трансплантатом (\%) }\end{array}$ & $\begin{array}{c}\text { 3агальна кількість } \\
\text { відновних оперативних втручань (\%) }\end{array}$ \\
\hline Перша група $(\mathrm{n}=44)$ & $43(18,1)$ & $51(10,4)$ \\
\hline Друга група $(\mathrm{n}=67)$ & $57(23,9)$ & $114(23,2)$ \\
\hline Третя група $(\mathrm{n}=90)$ & $98(41,2)$ & $189(38,4)$ \\
\hline Четверта група $(\mathrm{n}=41)$ & $40(16,8)$ & $138(28,0)$ \\
\hline Усього & $238(100)$ & $492(100)$ \\
\hline
\end{tabular}

Таблиця 3. Кількість пластик клаптями на живильній ніжці у хворих із дефектами покривних тканин залежно від ділянки ушкодження

\begin{tabular}{|c|c|c|c|c|}
\hline $\begin{array}{c}\text { Ділянка } \\
\text { ушкодження }\end{array}$ & $\begin{array}{c}\text { Перша група } \\
(\mathrm{n}=44) \\
(\%)\end{array}$ & $\begin{array}{c}\text { Друга група } \\
(\mathrm{n}=67) \\
(\%)\end{array}$ & $\begin{array}{c}\text { Третя група } \\
(\mathrm{n}=90) \\
(\%)\end{array}$ & $\begin{array}{c}\text { Четверта група } \\
(\mathrm{n}=41) \\
(\%)\end{array}$ \\
\hline Верхня кінцівка & - & $4(17,4)$ & $6(17,1)$ & $23(48,9)$ \\
\hline Нижня кінцівка & - & $14(60,9)$ & $25(71,4)$ & $13(27,7)$ \\
\hline Тулуб & - & $5(21,7)$ & $4(11,5)$ & $11(23,4)$ \\
\hline Усього & - & $23(100)$ & $35(100)$ & $47(100)$ \\
\hline
\end{tabular}


Усі клапті на ніжці поділяють на три групи залежно від срорми ніжки: плоскі, острівцеві, трубчасті.

Найнебезпечніші при пересадці були плоскі клапті, що мали сегментарний тип кровопостачання. Їх використовували для закриття десектів місцевими тканинами та віддаленими від донорської ділянки дефектів.

Живильною ніжкою острівцевого клаптя є судинний пучок (осьовий тип кровопостачання). Радіус ротації острівцевих клаптів залежить від довжини судинної ніжки, він стає ще більшим, коли для пересадки використовують клапоть на перисреричній судинній ніжці.

Трубчастий клапоть може мати як осьовий, так і сегментарний тип кровопостачання залежно від зони його фрормування.

Клапоть на живильній ніжці з тканин, які безпосередньо прилягають до десректу (місцеві клапті), давало найкращі результати при пересадці, тому що за своєю структурою, кольором, товщиною мав найбільшу схожість 3 відсутніми покривними тканинами над дефектом. За рахунок живильної ніжки кровопостачання та іннервація залишалися незмінними. Характеристика пересаджених тканин залишалася такою як і у донорській ділянці.

Місцеві клапті за типом їх переміщення поділяють на ротаційні, транспозиційні та ковзаючі.

При відсутності умов до виконання пластики місцевими тканинами використовували клапті на живильній ніжці зі суміжних анатомічних ділянок. При цьому живильна ніжка, як правило, зберігалася. Ця методика значно складніша за попередню, результати втручання можуть погіршуватися за рахунок ішемічних ускладнень з боку пересаджених тканин.

При пересадці невільних комплексів тканин із віддалених до дефекту анатомічних ділянок, кінцівкам надавали вимушеного положення для забезпечення зв'язку десректу з клаптем на термін, необхідний для утворення достатніх судинних зв'язків між пересадженими тканинами та РП (у середньому 14-16 діб). Після цього живильну ніжку відсікали.

Усього (другій - четвертій групах хворих) виконано 105 втручань складними клаптями (табл. 4).

У першій групі ( $n=44)$ хворим з обмеженою (до 5 см у діаметрі) ділянкою ушкодження шкіри та підлеглих тканин до глибокої фасції операції з використанням клаптів на живильній ніжці не виконували у зв'язку з відсутністю показань до реконструктивних втручань.
Хворим другої групи (n=67) з великою та надвеликою рановою поверхнею й пошкодженням м'яких тканин нижче глибокої фрасції було виконано 14 пластик клаптями 3 тканин навколо дефекту, з них 10 місцевих пластик плоскими ковзаючими клаптями, 3 - транспозиційними клаптями, 1 - ротаційним клаптем.

Шість оперативних втручань виконано клаптями 3 тканин, прилеглих до дефекту анатомічних ділянок: 1 острівцевим клаптем на периферичній ніжці, 2 - мостоподібних клапті (клапоть із двома живильними ніжками), 1 пластика плоским клаптем із використанням методики дерматензії (3 оперативні втручання).

Три операції виконано трубчастим мігруючим класичним клаптем (із віддаленої анатомічної ділянки). 23 оперативні втручання - складними клаптями. Післяопераційних ускладнень не було.

У третій групі (n=90) хворим із десектами покривних тканин, які виникли разом або унаслідок ушкодження кістково-суглобового апарату, виконано 35 оперативних втручань клаптями на живильній ніжці.

Шість пластик місцевими тканинами: 4 - ковзаючим клаптем, 1 - транспозиційним, 1 - ротаційним клаптем.

Два оперативні втручання виконано клаптями з тканин, прилеглих до десекту анатомічних ділянок: 1 - острівцевим клаптем на перисреричній ніжці, 1 пластика плоским клаптем. 22 операції виконано трубчастим мігруючим класичним клаптем та 5 плоскими клаптями (3 віддаленої анатомічної ділянки).

В одному випадку виник частковий некроз клаптя 3 потребою у виконанні повторного втручання.

Хворим четвертої групи (n=41) з поєднаною або множинною травмою, що супроводжується ушкодженням магістральних судин, нервів частковим або повним відокремленням кінцівки виконано 47 реконструкцій клаптями на живильній ніжці. 14 пластик - тканинами навколо дефекту: 11 - ковзаючим клаптем, 3 - транспозиційним клаптем. 11 оперативних втручань виконано клаптями 3 тканин, прилеглих до десректу анатомічних ділянок: 1 острівцевим клаптем на перисреричній ніжці, 6 пластик, плоским клаптем, 4 - втручання плоскими клаптями, які формували за допомогою методики тканинної дерматензії. 22 операції виконано трубчастим мігруючим класичним клаптем (з віддаленої анатомічної ділянки). Виник один випадок ускладнення у вигляді крайового ішемічного некрозу з повторним оперативним втручанням.

Таблиця 4. Кількість пластик клаптями на живильній ніжці у пацієнтів із десектами покривних тканин

\begin{tabular}{|l|c|c|}
\hline \multicolumn{1}{|c|}{ Група хворих } & $\begin{array}{c}\text { Кількість пластик клаптем } \\
\text { на живильній ніжці (\%) }\end{array}$ & $\begin{array}{c}\text { Загальна кількість } \\
\text { відновних оперативних втручань (\%) }\end{array}$ \\
\hline Перша група $(\mathrm{n}=44)$ & - & $51(10,4)$ \\
\hline Друга група $(\mathrm{n}=67)$ & $23(21,9)$ & $114(23,2)$ \\
\hline Третя група $(\mathrm{n}=90)$ & $35(33,3)$ & $189(38,4)$ \\
\hline Четверта група $(\mathrm{n}=41)$ & $47(44,8)$ & $138(28,0)$ \\
\hline Усього & $105(100)$ & $492(100)$ \\
\hline
\end{tabular}

Висновки 1. Використання васкуляризованих клаптів у 21,3 \% усіх можливих реконструкцій підвищило функціональні та косметичні результати лікування, знизило кількість ішемічних розладів та запальних процесів (1,9 \% післяопераційних ускладнень).
2. Ретельний підхід до вибору відновного втручання десректів покривних тканин, які зумовлені механічними ушкодженнями, дозволив досягти задовільних результатів у $98,9 \%$ випадків. 
СПИСОК ЛІТЕРАТУРИ

1. Белоусов А. Е. Пластическая реконструктивная и эстетическая хирургия / А. Е. Белоусов. - СПб. : Гиппократ, 1998. - 744 с.

2. Золтан Я. Пересадка кожи / Я. Золтан. - Изд-во : Академии наук Венгрии, 1984. - 303 c.

3. Battiston B. Compound or specially designed flaps in the lower extremities / B. Battiston, D. Ciclamini, J. B. Tang // Clin. Plast. Surg. - 2017. - Vol. 44 (2). - P. 287-297. doi: 10.1016/j.cps.2016.11.006.

4. Lower extremity reconstruction with free gracilis flaps / M. J. Franco, M. C. Nicoson, R. P. Parikh, T. H. Tung // J. Reconstr. Microsurg. - 2017. - Vol. 33 (3). - P. 218-224. doi: 10.1055/s-0036-1597568.
5. Perforating vessel as an alternative option of a recipient selection for posterior trunk - free flap reconstruction / Y. J. Lee, S. E. Baek, J. Lee [et al.] // Microsurgery. - 2018. doi: 10.1002/ micr.30369.

6. Versatility and "flap efficiency" of pedicled perforator / J. K. Wong, N. Deek, C. C. Hsu [et al.] // J. Plast. Reconstr Aesthet. Surg. -2017. - Vol. 70 (1). - P. 67-77. doi: 10.1016/j.bjps.2016.09.028.

7. Yasir M. Perforator flaps for reconstruction of lower limb defects / M. Yasir, A. H. Wani, H. R. Zargar // World J. Plast. Surg. - 2017. - Vol. 6 (1). - P. 74-81.

Отримано 04.08.18

Електронна адреса для листування: alena.ponomarenko@gmail.com

๑) O. V. Ponomarenko

Zaporizhzhia State Medical University

\section{CHOICE OF THE METHOD OF RECONSTRUCTION OF DEFECTS OF COVER TISSUES AND EXTREMITIES IN INJURED PATIENTS}

Summary. The volume of reconstructive interventions to restore the defects of the epithelial tissues, resulting from traumatic injury, determines the result from both a functional and aesthetic point of view.

The aim of the study - to choose the optimal method of restorative and reconstructive intervention to close the wound defects of the trunk and limbs after injury.

Materials and Methods. The study analyzed data of 242 patients with defects in the epithelial tissues of the trunk and extremities, which arose as a result of mechanical damage in the period 2008-2016. 697 surgical interventions were performed to patients, 492 of which $(70.6 \%)$ were surgery for the restoration of damaged tissues.

Results and Discussion. The patients were divided into 4 groups depending on the size, depth and degree of damage of the soft tissues and other structures of the trunk and limbs. Group I - 44 (18.2\%) patients with a limited (up to $5 \mathrm{~cm}$ in diameter) area of damage to the skin and underlying tissues to the deep fascia. It completed 61 (8.8\%) interventions. Group II - 67 (27.7\%) patients with extensive wound surface and soft tissue damage below the deep fascia. $144(20.6 \%)$ surgical interventions were performed in this group. The group III consisted of $90(37.2 \%)$ patients with defects in the epithelial tissues arising together or as a result of damage to the bone and joint apparatus. 272 (39\%) operations were performed. Group IV - 41 (16.9\%) patients with a combined or multiple injury, which was accompanied by damage to the great vessels, nerves, partial or complete separation of the limb. In this group, 220 (31.6\%) operations were performed.

Conclusions. 1. The use of vascular flaps in $21.3 \%$ of all possible reconstructions increased the functional and cosmetic results of treatment, reduced the number of ischemic disorders and inflammatory processes (1.9\% of postoperative complications). 2 . A careful approach to the choice of the restorative intervention of the defects of the epithelial tissues caused by mechanical damage made possible to achieve positive results in $98.9 \%$ of cases

Key words: wound defect; area of damage; limbs; flap; reconstructive interventions.

(Е. В. Пономаренко

Запорожский государственный медицинский университет

\section{ВЫБОР МЕТОДА РЕКОНСТРУКЦИИ ДЕФЕКТОВ ПОКРОВНЫХ ТКАНЕЙ ТУЛОВИЩА И КОНЕЧНОСТЕЙ У ТРАВМИРОВАННЫХ БОЛЬНЫХ}

Резюме. Объем реконструктивных вмешательств по восстановлению дефектов покровных тканей, возникающие вследствие травматического повреждения, определяет результат как с функциональной, так и с эстетической точки зрения.

Цель исследования - выбрать оптимальный метод восстановительно-реконструктивного вмешательства по закрытию раневых дефектов туловища и конечностей после травмы.

Материалы и методы. В работе проанализированы данные 242 больных с дефектами покровных тканей туловища и конечностей, которые возникли вследствие механического повреждения за период 2008-2016 гг. Пациентам было виполнено 697 оперативных вмешательств, из них 492 (70,6 \%) операции по поводу восстановления поврежденных тканей.

Результаты исследований и их обсуждение. Больные были разделены на 4 группы в зависимости от размеров, глубины и степени повреждения мягких тканей и других структур туловища и конечностей. Первая группа - 44 (18,2 \%) больных с ограниченным (до 5 см в диаметре) участком повреждения кожи и подлежащих тканей до глубокой фрасции. Им было выполнено 61 (8,8 \%) вмешательства. Вторая группа - 67 (27,7 \%) больных с обширной раневой поверхностью и повреждением мягких тканей ниже глубокой фрасции. В этой группе выполнено 144 (20,6 \%) оперативных вмешательства. Третью группу составили 90 (37,2 \%) пациентов с десректами покровных тканей, возникших вместе или в результате повреждения костно-суставного аппарата. Было выполнено 272 (39\%) операций. Четвертая группа - 41 (16,9 \%) больной с сочетанной или множественной травмой, которая сопровождалась повреждением магистральных сосудов, нервов, частичным или полным отчленением конечности. В этой группе было выполнено 220 (31,6 \%) операций.

Выводы. Использование васкуляризированных лоскутов в 21,3 \% всех возможных реконструкций повысило фрункциональные и косметические результаты лечения, снизило количество ишемических расстройств и воспалительных процессов (1,9 \% послеоперационных осложнений). Тщательный поход к выбору восстановительного вмешательства дефектов покровных тканей, обусловленных механическими повреждениями, позволил достигнуть положительных результатов в 98,9 \% случаев.

Ключевые слова: раневой дефект; область повреждения; конечности; лоскут; реконструктивные вмешательства 